AGH DRILLING, OIL, GAS • Vol. 32 • No. $1 \cdot 2015$

http://dx.doi.org/10.7494/drill.2015.32.1.211

\title{
Vitalij Kulynych*
}

\section{OPTIMAL DEMULSIFICATION METHOD SELECTION ON DEPOSIT LUBIATÓW}

\section{INTRODUCTION}

Petroleum rarely is extracted in the form of one phase, often in its composed from water, gas and pollution. One of the technical-economic problems during extraction of hydrocarbons is a high production of water from oil and gas wells. Water extracted with oil can act as free water (formation water) of in the form of an emulsion. It has a crucial influence on the oil extraction economy. Each year the production of water from oil and gas wells cost the oil industry more than 45 billion dollars. This amount includes the cost of extracting water on the surface and its utilization or injection to deposits, as well as all surface installations necessary for the extraction of formation water from wells producing hydrocarbons. It also covered costs associated with efforts to make all the necessary processes did not impact environment negatively [3].

According to world statistics $25-35 \%$ production oil constitute emulsions. They contain the considerable amounts of formation water extracted from deposits. This water must be separated from the oil, cleaned to appropriate values determined by norms and discharged to surface tanks or again injected to a deposit.

The article presents laboratory tests in order to select of the optimal demulsifier for the selected oil by thermochemical method for selected oil.

\section{OIL EMULSIONS}

Emulsions are two-phase system, consisting of at two immiscible liquid. In emulsion one liquid is dispersed in the other in the form of drops.

* AGH University of Science and Technology, Faculty of Drilling, Oil and Gas, Krakow, Poland, Ph.D. Student 
The continuous phase constitutes the medium in which droplets of the dispersed phase are suspended (disperse medium). Dispersed phase create very small droplets of other liquids, arranged in a continuous medium. This phase is called the dispersed or the internal [6].

In case of emulsion overbalancing amounts, water is one of liquid phases, the second one is less polar oil phase. So the emulsion produced during oil extraction can be classified in three groups (Fig. 1):

- "water in oil" (hydrophobic - symbol W/O) - oil is a constant phase (that is petroleum or her products), and with dispersed phase water;

- "oil in the water" (hydrophilic - O/W) - water is a constant phase, and oil is a dispersed phase;

- multiple complex of emulsion.

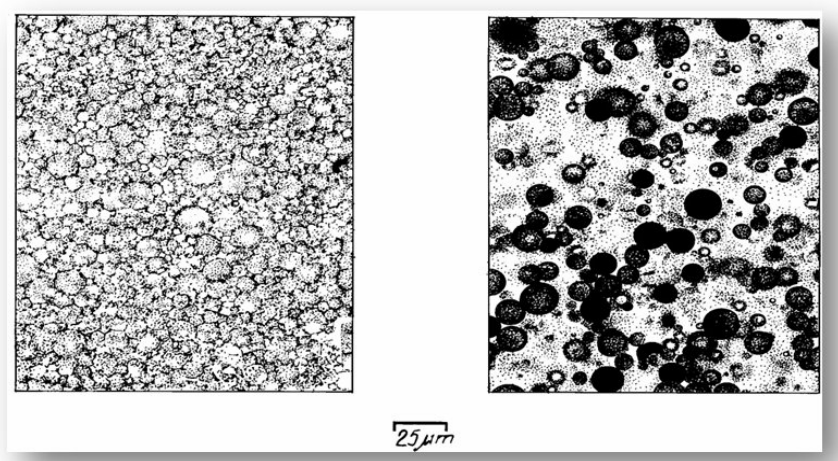

Fig. 1. Microphotography of emulsion $\mathrm{W} / \mathrm{O}$ and $\mathrm{O} / \mathrm{W}[2]$

One of the reasons for the migration of water through the oil saturated rocks is that the water has a higher surface tension than oil, which results in capillary forces in the pores and crevices pulling up water faster than crude oil.

Water, flowing in the capillaries, has higher speed than the oil due to lower viscosity, causing lesser resistance to friction. Oil emulsions are formed in the borehole and in the operational process on the surface, the most important argument proving this hypothesis is the fact that the viscosity of the emulsion is many times higher than the oil viscosity (up to 200 times) [5].

In the capillaries the oil and water flow is laminar, whether a significant amount of energy liquids is needed for emulsion for being created e.g. in the turbulent flow or during mechanical mixing up these two.

Intensive mixing of the two liquids is in the hydrocarbons extraction:

- with self-outflow from wells - a significant amount of gas in the form of bubbles gets through the liquid upwards, taking the drops of water, followed by the sudden mixing of liquids in the borehole; 
- with a mechanical way of extracting oil from deposits by the use of gas lift - this effect of mixing required is achieved for the spontaneous flow of oil with their own gas;

- at extracting oil with piston pumps - the intensive stirring of the liquidis takes place during the flow through the valves;

- after getting from the borehole - oil with water is flowing through the series of valves and rotary pumps, to get to tanks through pipelines [4].

Depending on the oil and brine chemical composition different methods of the demulsification are applied. The most long-lasting emulsions are created from paraffin oils with the high content of asphaltenes and formation waters with high mineralization. They often require simultaneous applying a few methods of the demulsification.

Method of the demulsification is selected depending on the oil and emulsion. In the industry a following methods of breaking emulsion are used: thermochemical, mechanical, electric.

In the thermochemical method, oil emulsion is separated on oil and water as a result of the influence on the emulsion increased temperature and the surfactants - so-called demulsifiers. The high temperature accelerate and improves their effectiveness. Temperature increases solubility of demulsifiers and oil, whereas the fall in the viscosity enables the faster joining of dispersed droplets of water into larger conglomerations and falling to the bottom of the container as a result of the force of gravity.

Demulsifiers are chemical compounds with surface-active properties, capable of reducing the tension on the surface of the contact phase. They have the characteristic structure of the amphiphilic (pin) because they contain asymmetrically distributed molecule, with both polar hydrophilic groups and non-polar - hydrophobic. Due to such structure, they have the ability to set up in a way that is oriented on the surface phase contact and reduce the surface tension [1].

To achieve a better effect of emulsions separation appropriate surfactant should be selected based on laboratory tests due to the properties of oil or emulsion. Crude asphaltenes contents, wax and solid particles and the temperature of the fluid reservoir are very important parameters in the surfactant selection. Based on this parameters demulsifier for phase separation may be selected.

Mismatched surfactant may result in the creation new type of emulsion, which may to difficult to separate during industrial processes. The applied surfactant - demulsifier must contact with the surface of the emulsified droplets of the water and hydrocarbon layers.

\section{TESTING OF DEMULSIFICATION OIL EMULSIONS FROM THE LUBIATÓW DEPOSIT}

The purpose of the laboratory tests was selection the demulsifiers for the crude oil produced from the Lubiatów deposit on the Polish Lowlands.

Two surfactants T-2490E and T-02121 German company "Brenntag" (Tab. 3), obtained from KRNiGZ Lubiatów and 3 types of oils (oil from the Lubiatów deposit, oil from 
the Lubiatów deposit with the fuel oil addition and degassed oil from the Lubiatów deposit) were tested.

The measurements of following physicochemical oil properties were conducted (Tab. 1):

- the measurement of density (pycnometer method),

- the measurement of surface tension (stalagmometric method),

- the coefficient of dynamic viscosity,

- acid number (potentiometric titration of a sample of oil using an alcoholic-aqueous solution of $\mathrm{KOH})$.

Table 1

The values of the surface tension of oil

\begin{tabular}{|l|c|c|c|}
\hline \multicolumn{1}{|c|}{ Type of oil } & $\begin{array}{c}\text { Density } \\
{\left[\mathrm{kg} / \mathrm{m}^{3}\right]}\end{array}$ & $\begin{array}{c}\text { Surface tension on the } \\
\text { border } \sigma[\mathrm{N} / \mathrm{m}]\end{array}$ & $\begin{array}{c}\text { Acid number } \\
{[\mathrm{mg} \mathrm{KOH} / \mathrm{g}]}\end{array}$ \\
\hline Oil Lubiatow & 797 & $47.35 \cdot 10^{-3}$ & 0.35 \\
\hline Oil Lubiatow modified & 825 & $28.48 \cdot 10^{-3}$ & 0.82 \\
\hline Oil Lubiatow degassed & 843 & $44.92 \cdot 10^{-3}$ & 0.55 \\
\hline
\end{tabular}

The viscosity measurements by Hoppler viscometer at three different temperatures of $20^{\circ} \mathrm{C} 30^{\circ} \mathrm{C} 40^{\circ} \mathrm{C}$ were made (Tab. 2).

Table 2

Values of the viscosity of oil Lubiatów, modified and degassed in temperatures $20^{\circ} \mathrm{C}, 30^{\circ} \mathrm{C}, 40^{\circ} \mathrm{C}$

\begin{tabular}{|c|c|c|c|}
\cline { 2 - 4 } \multicolumn{1}{c|}{} & \multicolumn{3}{c|}{$\begin{array}{c}\text { Dynamic coefficient of oil viscosity } \\
\mu \cdot 10^{-3}[\mathrm{~Pa} \cdot \mathrm{s}]\end{array}$} \\
\hline $\begin{array}{c}\text { Temperature } \\
{\left[{ }^{\circ} \mathrm{C}\right]}\end{array}$ & Oil Lubiatów & Oil modified & Oil degassed \\
\hline 20 & 2.75 & 5.77 & 5.65 \\
\hline 30 & 2.28 & 4.75 & 5.00 \\
\hline 40 & 1.89 & 3.68 & 3.71 \\
\hline
\end{tabular}

The demulsifier T-2490 is used for the breaking of the emulsion water in crude oil, giving a clean oil that meets the specifications. Very good phases separation is achieved and good qualitaty water is obtained using this demulsifier (Tab. 3).

Demulsification laboratory tests consisted of several stages. Methodology of measurments in the first stage were as follows: measuring cylinders with a capacity of $50 \mathrm{~cm}^{3}$ with 
a graduated scale was filled with $20 \mathrm{~cm}^{3}$ of oil from Lubiatów deposit, brine and demulsifier which have been made previously in the laboratory in the amounts shown in the Table 4. There were also conducted tests without the demulsifier.

Table 3

Description demulsifier T-2490 [8]

\begin{tabular}{|l|l|}
\hline Density & $890-900 \mathrm{~kg} / \mathrm{m}^{3}$ \\
\hline Freezing point & $-35^{\circ} \mathrm{C}$ \\
\hline Flashpoint & $15^{\circ} \mathrm{C}$ \\
\hline Solubility & Hydrocarbons \\
\hline Chemical description & $\begin{array}{l}\text { The mixture of polymers, esters, resins, amines, acids and/or } \\
\text { sulphonates }\end{array}$ \\
\hline Recommended use & $\begin{array}{l}\text { Dosed continuously allows to obtain a dehydrated oil from less than } \\
0.5 \% \text { of sludge solids and water. The water will be of sufficient } \\
\text { quality for recycling or other uses }\end{array}$ \\
\hline
\end{tabular}

Table 4

Summary of test tubes with different chemical composition

\begin{tabular}{|l|l|}
\hline \multicolumn{1}{|c|}{ Sample } & \multicolumn{1}{c|}{ The chemical composition of test tubes } \\
\hline I & $10 \mathrm{ml}$ of water $+20 \mathrm{ml}$ of oil \\
\hline II & $10 \mathrm{ml}$ of brine $+20 \mathrm{ml}$ of oil \\
\hline III & $0.5 \mathrm{ml}$ of $0,1 \%$ surfactant $(\mathrm{T}-2490 \mathrm{E})+10 \mathrm{ml}$ of brine $+20 \mathrm{ml}$ of oil \\
\hline IV & $0.5 \mathrm{ml}$ of $1 \%$ surfactant $(\mathrm{T}-2490 \mathrm{E})+10 \mathrm{ml}$ of brine $+20 \mathrm{ml}$ of oil \\
\hline V & $0.5 \mathrm{ml}$ of $0,1 \%$ surfactant $(\mathrm{T}-02121)+10 \mathrm{ml}$ of brine $+20 \mathrm{ml}$ of oil \\
\hline VI & $0.5 \mathrm{ml}$ of $1 \%$ surfactant $(\mathrm{T}-02121)+10 \mathrm{ml}$ of brine $+20 \mathrm{ml}$ of oil \\
\hline VII & $0.5 \mathrm{ml}$ of $1 \%$ surfactant $(\mathrm{T}-2490 \mathrm{E})+10 \mathrm{ml}$ of water $+20 \mathrm{ml}$ of oil \\
\hline VIII & $0.5 \mathrm{ml}$ of $1 \%$ surfactant $(\mathrm{T}-02121)+10 \mathrm{ml}$ of water $+20 \mathrm{ml}$ of oil \\
\hline
\end{tabular}

Samples were carefully mixed the samples for $10 \mathrm{~min}$, then after the time $T$ of respectively $0.5,1,2,3,24,48$ hours read on the scale of the measuring cylinder volume of water separated. Measurements were made at temperatures $20^{\circ} \mathrm{C}$ and $40^{\circ} \mathrm{C}$ for the listed above surfactants. After mixing and leaving emulsion, for half an hour water instantly separated from the oil, it proves that the density of the oil is low, no mixing of the two phases occurs.

Therefore, in the second stage, the oil was modified by adding fuel, which includes asphaltenes and resins, natural emulsifiers reduce the surface tension (Fig. 2). These natural emulsifiers increase viscosity and increasing doses of the demulsifier in the sample VII and VIII. 


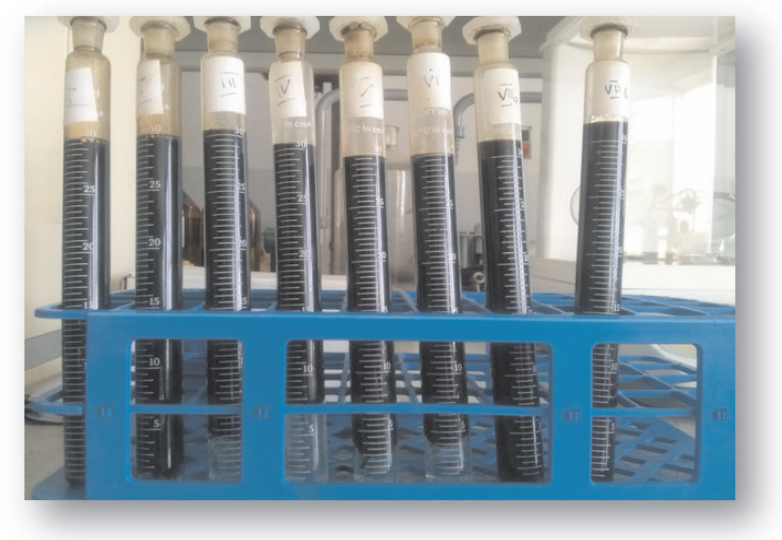

Fig. 2. Amount of separate water from oil modified after 1 hour at a temperature of $20^{\circ} \mathrm{C}$

The graph of the relation of the amount stayed of secreted oil from the time and the amount of demulsifier on the basis of these results has been drawn (Fig. 3). The results presented relate to the measurement temperature of $20^{\circ} \mathrm{C}$.

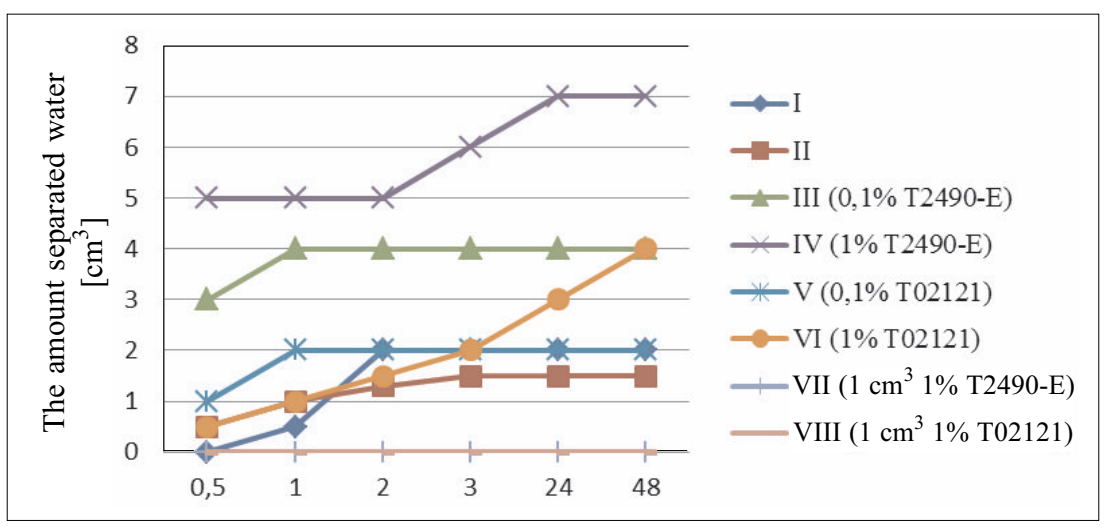

Time $[\mathrm{h}]$

Fig. 3. The dependence of the quantity of water separated from oil modified since the time, quantity and concentration of the demulsifier at a temperature $20^{\circ} \mathrm{C}$

Note, however, that the mismatched concentration of demulsifiers added to oil may cause the emulsion stabilization or new type of emulsion creation. This emulsion can be difficult to separate as in the case of samples VII and VIII with increased amount of demulsifier.

The same tests were performed in a temperature of $40^{\circ} \mathrm{C}$ for the time $T=1.2,3,24$, 48 hours (Fig. 4). 


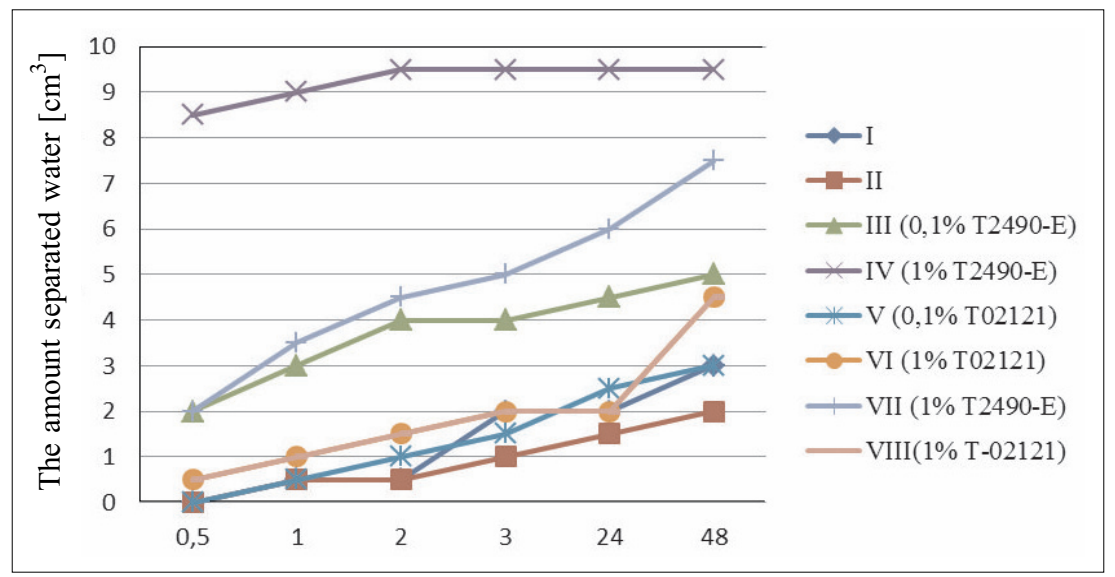

Time $[\mathrm{h}]$

Fig. 4. The dependence of the quantity of water separated from modified oil of the time and concentration of the demulsifier at a temperature $40^{\circ} \mathrm{C}$

The third stage of the study was to prepare degassed oil. Measurement rely on natural separation of light hydrocarbon fractions by leaving and degassing the oilwithin two weeks. The hydrocarbon material loss from crude oil was about 1/3 volume.

Methodology of demulsification measurements of evaporated oil was as follows: measuring cylinders with a capacity of $50 \mathrm{~cm}^{3}$ were filled into $20 \mathrm{~cm}^{3}$ vaporized oil, and $10 \mathrm{~cm}^{3}$ of brine and solutions demulsifier 0.1 and $1 \%$ surfactant T-2490 and T-02121, in order to verify the effectiveness of demulsifier based on previous research.

From the graph below can be seen the amount of separated volumes of water at a dosage of both demulsifiers T-2490 and T-02121-E only at different concentrations (Fig. 5).

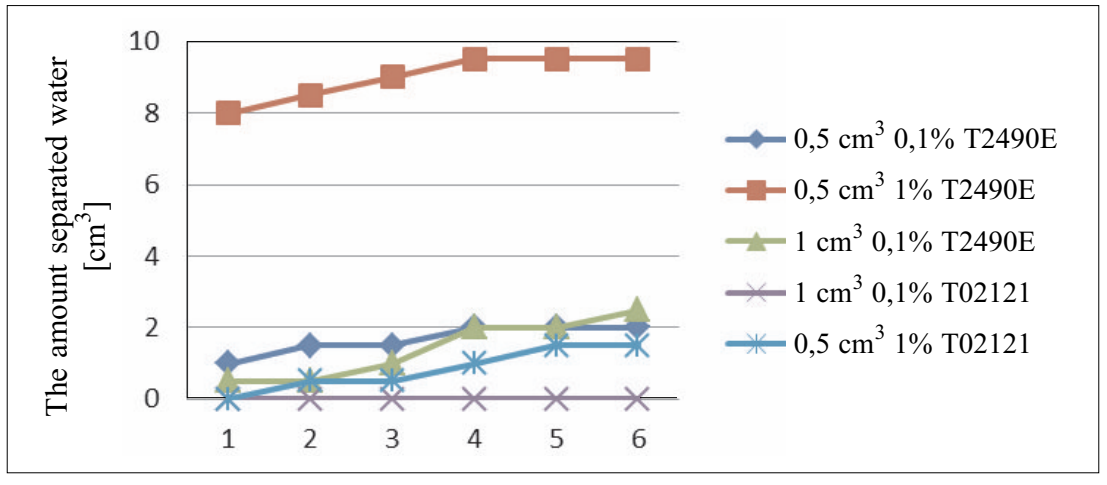

Time $[\mathrm{h}]$

Fig. 5. The dependence of the quantity of water separated from oil degassed since the time, quantity and concentration of the demulsifier at a temperature $20^{\circ} \mathrm{C}$. 
Later, the oil samples were placed in a thermostat at $40^{\circ} \mathrm{C}$ for a certain time $T=1.2,3$, 24, 48 hours (Fig. 6). The results are given in the chart below:

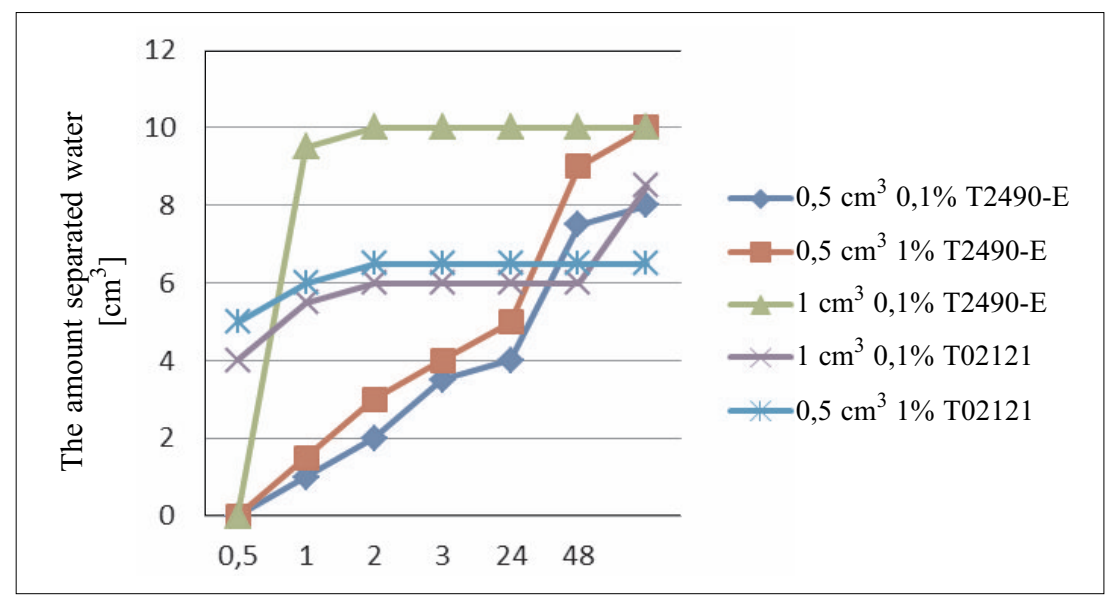

Time $[\mathrm{h}]$

Fig. 6. The dependence of the quantity of water separated from oil degassed since the time and quantity of demulsifier T-2490-E and T-02121 at $40^{\circ} \mathrm{C}$

\section{RESULTS}

Demulsifiers performance impact for oil from Lubiatów could not be determined due to the very fast breaking of the emulsion for till 0.5 hours. This was due to very low density $\left(797 \mathrm{~kg} / \mathrm{m}^{3}\right)$ and viscosity $\left(2.75 \cdot 10^{-3} \mathrm{~Pa} \cdot \mathrm{s}\right)$ of the tested oil. As a result the studies were modified for oil (oil from Lubiatów + addition of the fuel oil). The most effective for oil-modified at $20^{\circ} \mathrm{C}$ was a demulsifier T-2490E, after application of the compound of a concentration $0.5 \mathrm{~cm}^{3}$ and $1 \%$ in $30 \mathrm{~cm}^{3}$ emulsion after $0.5 \mathrm{~h}$ the amount of separated water was $5 \mathrm{~cm}^{3}$, which is $50 \%$ of the total amount of added water and increased to $7 \mathrm{~cm}^{3}(70 \%)$ after 48 hours. The second test demulsifier T-02121 slowly evolved water and the largest number of separate water was observed at $4 \mathrm{~cm}^{3}(40 \%)$ after 48 hours. Sample No. 1 and 2 not containing surfactant showed a low amount of separated water $\left(2 \mathrm{~cm}^{3}\right.$ and $1.5 \mathrm{~cm}^{3}$ respectively $20 \%$ and $15 \%$ ).

The next step was to heating oil at $40^{\circ} \mathrm{C}$. As the temperature increases the rate of the increase demulsification process. T-02121 emulsifier slowly exuded water: at $0.1 \% 3 \mathrm{~cm}^{3}$ water $(30 \%)$, at a concentration of $1 \%$ of the total amount of separated water was $4.5 \mathrm{~cm}^{3}$ (45\%). To break up the oil-water emulsions, oil-brine proved to be the most effective demulsifier Brenntag T-2490-E with a concentration of $1 \%$. After 0.5 hours a demulsifier separated $8.5 \mathrm{~cm}^{3}$ of brine $(85 \%)$, after 48 hours. $9.5 \mathrm{~cm}^{3}(95 \%)$. Demulsifier T-2490-E 
proved to be very effective for demulsification of water at $40^{\circ} \mathrm{C}$. After 48 hours, the impact evolved emulsion wody $7.5 \mathrm{~cm}^{3}$, which represents $75 \%$.

Oil evaporation process, in which light hydrocarbons leaked, was carried in the third stage of tests. As the result was density of oil has increased to $843 \mathrm{~kg} / \mathrm{m}^{3}$ and a viscosity of $5.65 \cdot 10^{-3} \mathrm{~Pa} \cdot \mathrm{s}$. Oil samples for testing with varying concentration of surfactant (demulsifier T-2490-E and T-02121) were selected. In the case of a degassed crude oil also turned out to be the most effective demulsifier T-2490 a concentration of 1\% (amount of separated water was $95 \%$ ). In contrast, the weakest impact demulsifier T-02121 showed a concentration of $0.1 \%$ in an amount of $0.1 \mathrm{~cm}^{3}$, which does not cause water separation even at a temperature of $40^{\circ} \mathrm{C}$. It can be concluded, therefore, that increasing the concentration and temperature of surfactant, increase the amount of water separated from the emulsion of each demulsifier.

\section{CONCLUSIONS}

All tested delmusifiers can be used for separating an emulsion of analyzed crude oil. In any case, the increase in temperature causes an increase in separation of water from the emulsion.

It can be concluded that the increased temperature accelerates the process of demulsification and increases its efficiency. Under its influence the mutual solubility of the demulsifiers and oil increases, and a decrease in viscosity allows faster connection of the dispersed water droplets into larger conglomerates, and makes it easier to fall to the bottom of the tank by gravity. Due to this phenomenon to releasing water from the emulsion purulent is easier.

\section{REFERENCES}

[1] Bęben D.: Badanie wpływu demulgatorów na układ ropa naftowa - woda $w$ celu uzyskania rozdziału faz. Nafta-Gaz, czerwiec 2007.

[2] Chyrynos M.L. [VE], Taylor A.T. [VE], Taylor S.E. [GB]: Sposób poluchenyja emulsyy nefty $v$ vode s vysokym sootnoshenyem vnutrennej fazy. (Способ получения емульсии нефти в воде с высоким соотношением внутренней фазы). Patent nr RU2009708.

[3] Falkowicz S., Dubiel S., Cicha-Szot R.: Laboratoryjne studium porównawcze ośrodków chemicznych stosowanych w zabiegach ograniczania dopływu wody do odwiertów gazowych. Versita, 2014.

[4] Janocha A.: Zastosowanie nowej generacji środków chemicznych do rozdziatu zemulgowanych układów ropa naftowa-woda. Wiertnictwo Nafta Gaz, t. 23/1, 2006. 
[5] Jewulski J., Zagrajczuk D.: Badania laboratoryjne demulgacji rop naftowych metodq termochemicznq. Wiertnictwo Nafta Gaz, t. 24, z. 1, 2007.

[6] Konsling Z.: Zarys przeróbki ropy naftowej i gazu ziemnego. Skrypty Uczelniane nr 721, Wydawnictwa AGH, Kraków 1980.

[7] Kulynych V.: Wybór optymalnej metody demulgacji na wybranym złożu. Master Thesis, WWNiG AGH UST, 2014.

[8] KRNiGZ Lubiatów (unpublished). 